\title{
An Inventory of Tortoise Beetles (Cassidinae) in Post Harvest Rice Field Ecosystem Area, Serdang Menang Village, Sirah Pulau Padang Sub- district
}

\author{
Ari Sugiarto \\ Email: sugiartoari13@gmail.com
}

\begin{abstract}
Diversity of plants species in post harvest rice field ecosystem area tends to be higher compared to before harvest. Tortoise beetles can be a threat to plants species that exist in rice field ecosystem area. Serdang Menang Village has a fairly extensive rice field ecosystem area. An inventory of tortoise beetles in rice field ecosystem area, Serdang Menang Village will be very helpful in potential estimating of tortoise beetles to plants that exist in rice field ecosystem area, Serdang Menang Village. Determination of this sampling location was done randomly in post harvest rice field ecosystem area, Serdang Menang Village. The sampling method uses small insecting net and hand picking methods. Species of tortoise beetles found were 5 species (Aspidomorpha miliaris, Cassida subreticulata, Cassida circumdata, Cassida sp., dan Doloyala sp.) of a total 3 genera. Cassida circumdata and Aspidomorpha miliaris is tortoise beetles species that easiest to be found in this rice field ecosystem area which indicates that population is more than any species of tortoise beetles found. Cassida circumdata and Aspidomorpha miliaris can be major threat in rice field ecosystem area compared any species of tortoise beetles that found because a population is estimated to be more.
\end{abstract}

Keywords: Post harvest rice field ecosystem area, Potential threat, Tortoise beetles

\section{Introduction}

Tortoise beetles are insects included in the subfamily Cassidinae. Tortoise beetles have a role in controlling certain plant populations. Based on the research of Asadi et al. (2013), tortoise beetle from species of Cassida rubiginosa can reduce biomass from Cirsium arvense. But on the other hand this turtle beetle can be a threat to plants by eating plant leaves. According to Millar et al. (2003), Tortoise beetles leaves a circular or irregular mark on leaf's surface to eliminate most of a leaf's surface until only a leaves are left over. According to Capinera (2015), development of turtles from eggs to adults takes about 40 days. In its natural ecosystem, population of these tortoise beetles can be controlled using biological agents Enoggera nassau, Neopolycystus insectifurax (Withers, 2014), Tetrastichus cassidus and Eucelatoriopsis dimmocki (Capinera,
2015). Chemical control can be carried out using $\mathrm{H}_{2} \mathrm{O}$ and $\mathrm{MeOH}$ solvents, proven to reduce the ability of shields in tortoise beetle larvae (Vencl et al., 2005).

Tortoise beetles can be found in low level vegetation such as in rice field ecosystem. In Serdang Menang Village, Sirah Pulau Padang Sub-district, Ogan Komering Ilir District there is a fairly extensive area of rice fields. At post harvest, species of plant found in rice field ecosystem area tend to be more diverse than before harvest. High levels of plant diversity certainly support a population of tortoise beetles. Need to do an inventory of tortoise beetles in rice field ecosystem area to see its potential threat for plant species found in rice field ecosystem area in Serdang Menang Village, Sirah Pulau Padang Sub-district, Ogan Komering Ilir District. 


\section{Research Methods}

This inventory was carried out in postharvest rice field ecosystem area in Serdang Menang Village, Sirah Pulau Padang Subdistrict, Ogan Komering Ilir District in November 2018. Determination of sampling locations was determined randomly in rice field ecosystem area. Samples was taken with hand picking and insecting net a small methods, considering that species of tortoise beetles was

\section{Results and Discussion}

Based on inventory that haa been done in post harvest rice field ecosystem area, Serdang Menang Village, Sirah Pulau Padang Sub-district, Ogan Komering Ilir District.

Table 1. Species of tortoise beetles that found in post harvest rice field ecosystem area, Serdang

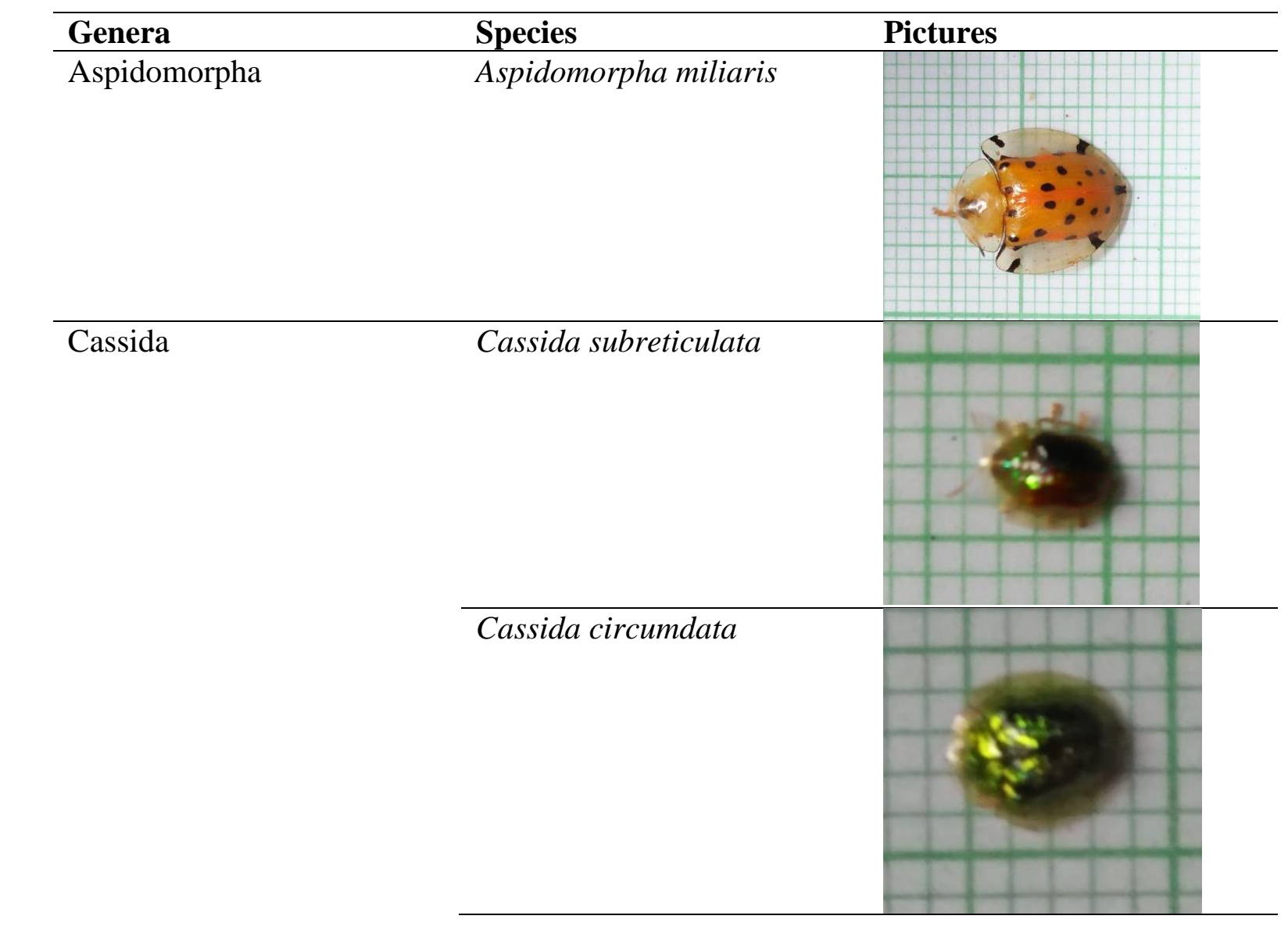

relatively calm and a flight distance was not too far away which made it easy to catch it. Samples obtained were then photographed on millimeter paper to identify of species. After being photographed, captured tortoise beetles is released again to preserve it. Identification of tortoise beetles species obtained is done by matching picture of tortoise beetle species of that has been identified.

\section{Menang Village, Sirah Pulau Padang Sub-district, Ogan Komering Ilir District}




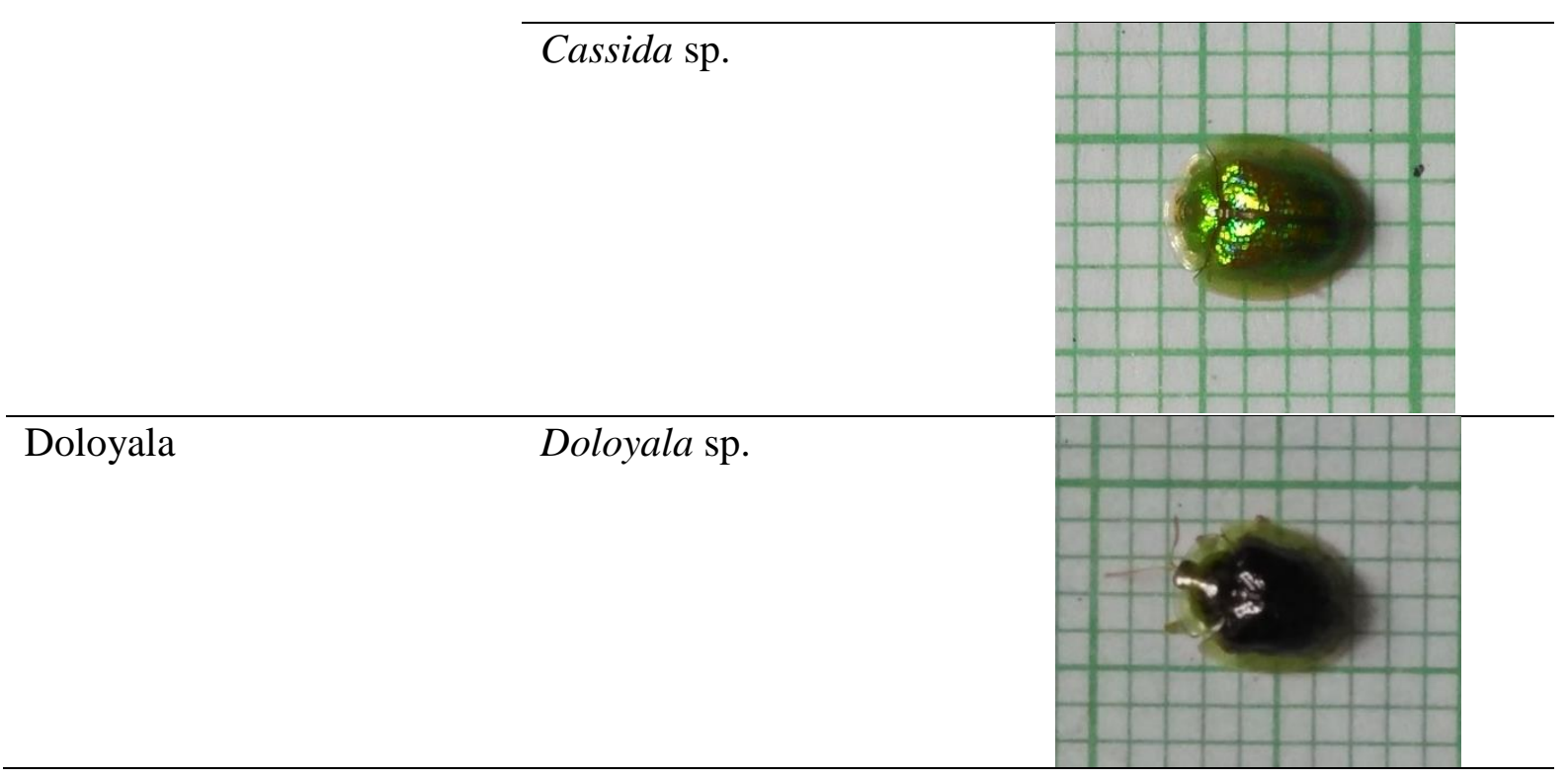

Found 5 species of tortoise beetles from a total of 3 genera in post harvest rice field ecosystem area, Serdang Menang Village. Species of tortoise beetles found are Aspidomorpha miliaris, Cassida subreticulata, Cassida circumdata, Cassida sp., And Doloyala sp. The species of Cassida circumdata and Aspidomorpha miliaris are easiest to be found in this ecosystem area of rice fields. Species of tortoise beetles found in post-harvest rice field ecosystem area is indeed not much, but if a population is abundant this can be a threat to species of plants that grow or are planted in this rice field ecosystem area. According to Millar et al. (2003), a threat from a tortoise beetle, which is eating plant leaves that leave a circular or irregular mark on a leaf's surface to eliminate most of leaf's surface until only leaves are left over.

Tortoise beetles in natural ecosystem certainly has enemies that can control a population of this tortoise beetle. According to Withers (2014) and Capinera (2015), in natural ecosystem a populations of these tortoise beetles can be controlled using biological agents Enoggera nassau, Neopolycystus insectifurax Tetrastichus cassidus and Eucelatoriopsis dimmocki.

According to Flinte et al. (2015), population of tortoise beetles from the species of Coptocycla arcuata, Omaspides trichroa, dan Platyphora axillaris in
September until November month is more than in othes months. This can indicate that a population of tortoise beetles in rice field ecosystem area, Serdang Menang Village indeed is more commonly found at post harvest time. The harvest time in rice fields of Serdang Menang Village is at end of May to beginning of August. Large population of tortoise beetles at the time of post harvest is also supported by species of plant found in more diverse areas of post harvest rice fields than before harvest. According to Capinera (2015), development of tortoise beetles from eggs to adults takes about 40 days.

Apart from the estimated adverse effects, of course tortoise beetle still has an important role to play in ecosystems, as the results of research conducted by Asadi et al. (2013), a tortoise beetle from species of Cassida rubiginosa can control a population of Cirsium arvense by eating leaves so that it can reduce biomass from Cirsium arvense plant.

Tortoise beetles will not pose a threat to rice field ecosystem area if there is a balance between a population of tortoise beetles and its natural enemies. If this happens, the existence of tortoise beetles in rice fields ecosystem area will certainly have a positive impact. The ability possessed by this tortoise beetle can help 
control wild plant populations in post harvest rice field ecosystem area.

\section{Conclution}

Diversity of tortoise beetles in rice field ecosystem area, Serdang Menang Village is classified as moderate with only found 5 species in a total of 3 genera. Cassida circumdata and Aspidomorpha miliaris are easiest species of tortoise beetles to be found in this rice field ecosystem area which indicates that a population is more than any other species of tortoise beetle found. Cassida circumdata and Aspidomorpha miliaris can be a major threat to rice fields ecosystem area compared to other species of tortoise beetles found because of their estimated population.

\section{References}

Asadi, G., Reza, G., Javad, K., Alireza, B., and Heinz, M.Z. 2013. Host Impact and Specificity of Tortoise Beetle (Cassida rubiginosa) on Canada Thistle (Cirsium arvense) in Iran. Weed Technology. 27(2): 405-411.

Capinera, J.L. 2015. Golden Tortoise Beetle, Charidotella (=Metriona) bicolor (Fabricius) (Insecta: Coleoptera: Chrysomelidae). Gainesville: Entomology and Nematology Department; UF/IFAS Extension.

Flinte, V., Ethel, H., Barbara, M.M., Anne, C.M.L., Gabriel, K., Ricardo, F.M., and Margarete, V.M. 2015. Biology and Phenology of Three Leaf Beetle Species (Chrysomelidae) in A Montane Forest in Southeast Brazil ZooKeys. 547(1): 119-132.

Millar, J.G., T.D. Paine., K.A. Campbell, R.W. Garrison, and S.H. Dreistadt. 2003. Eucalyptus
Tortoise Beetle, Integrated Pest Management for Home Gardeners and Landscape Professionals. Davis: UC Statewide IPM Program, University of California.

Vencl, F.V., Flávia, N., Bengt, J.A., Donald, M.W., and Douglas, J.F. 2005. Dietary Specialization Influences the Efficacy of Larval Tortoise Beetle Shield Defenses. Oecologia.

Withers, T. 2014. Eucalyptus Tortoise Beetle Biocontrol. (Online). www.scionresearch.com/service s. Accessed on November 11, 2018. 